\title{
Library Teaching Anxiety: Understanding and Supporting a Persistent Issue in Librarianship
}

\author{
Kacy Lundstrom, Britt Fagerheim, and Stephen Van Geem
}

\begin{abstract}
Teaching roles in academic libraries can be accompanied by a great deal of anxiety. This study surveyed librarian attitudes toward their teaching role and librarians' experiences with teaching anxiety. Sixty-four percent of librarians participating in the survey said they experienced teaching anxiety, including 65.10 percent experiencing physical symptoms and 73.43 percent of librarians who experienced teaching anxiety experiencing psychological symptoms. Findings indicate tension between sustaining a work-life balance and managing physical and psychological symptoms. Based on these findings, the researchers propose supports that can help mitigate the adverse effects of teaching anxiety on library instructors.
\end{abstract}

\section{Introduction}

Teaching is an inherently vulnerable task, especially when done well. Parker Palmer describes the vulnerability of teaching this way: "A good teacher must stand where personal and public meet, dealing with the thundering flow of traffic at an intersection where 'weaving a web of connectedness' feels more like crossing a freeway on foot." ${ }^{1}$ Teaching librarians have distinct teaching experiences that place them in unique situations. One-shot sessions, in particular, require an adeptness and confidence from library instructors. Often, librarians are asked to cover multitudes of research-related learning outcomes with students they see once (or just a few times) and don't have established rapport with, teaching research tools and skills that many students have intense anxiety about or outright animosity toward.

Additionally, many librarians do this intermittently, in addition to other duties that may fill the majority of their time. It's common practice for librarians to be asked to teach as part of their major and minor library roles, which supports a common narrative of librarians "wearing many hats." Sometimes, these teaching roles are welcome. In other cases, these teaching roles are accompanied by a great deal of anxiety, which can result from a lack of experience, lack of confidence, fear of failure, little to no educational background in teaching, or connections to other anxiety disorders.

The issue of teaching anxiety among librarians arose at the authors' institution during discussions of potential changes to the subject librarian program. The librarian researchers

\footnotetext{
${ }^{*}$ Kacy Lundstrom is Head of Learning and Engagement Services in the Utah State University Libraries at Utah State University; email: kacy.lundstrom@usu.edu. Britt Fagerheim is Reference E Instruction Librarian in the Utah State University Libraries at Utah State University; email: britt.fagerheim@usu.edu. Stephen Van Geem is Assistant Professor in the Department of Sociology, Social Work, and Anthropology at Utah State University; email: stephen.vangeem@usu.edu. @2021 Kacy Lundstrom, Britt Fagerheim, and Stephen Van Geem, AttributionNonCommercial (https://creativecommons.org/licenses/by-nc/4.0/) CC BY-NC.
} 
both have major instructional and liaison components to their roles and are housed in the "teaching unit" of the library. Utah State University is a land-grant, public research university with 27,000 students. During these discussions, it became apparent that library instruction was creating anxiety among some of the subject librarians, which contributed to a fraught atmosphere. These discussions led the researchers to explore three major questions; first, what are librarian attitudes toward their teaching role, especially if their teaching role is a minor part of their position; second, how do librarians experience teaching anxiety; and third, how does teaching anxiety relate to their attitudes toward teaching?

The goal of this research is to move toward solutions about how the library profession can alleviate issues of teaching anxiety and better support library instructors who experience it. Some issues that contribute to teaching anxiety are structural, exacerbated by budget constraints and the need in many libraries for librarians to take on roles that include teaching, in addition to other expectations. By better understanding the depth and causes of teaching anxiety, the profession can help librarians mitigate teaching anxiety and build supports for stronger teaching foundations.

\section{Literature Review}

A small body of literature focuses on how librarians experience teaching anxiety. In a previous study, "The Academic Librarian as Instructor: A Study of Teaching Anxiety," Kaetrena Davis looked at teaching anxiety among academic librarians from the view of librarians' perceptions of themselves as teachers. ${ }^{2}$ The study highlighted the growing role of instruction for academic librarians and the accompanying anxiety this might cause some librarians. Davis's study identified causes of anxiety among classroom teachers, whether these causes also applied to academic librarians, and whether librarians' perceptions of themselves as teachers influenced anxiety experienced by librarians.

Other research includes emotions and identity of teaching librarians, which touch on anxiety and potential causes or supports, often as a portion of a larger research question. A study with Canadian librarians looking at librarians' experiences with their teaching roles found three primary challenges for the teaching librarians, one of which included intrapersonal challenges. The authors include within intrapersonal challenges the characteristics of nervousness or fear of public speaking, as well as feelings of being unprepared to teach. ${ }^{3} \mathrm{~A}$ study of librarians in Poland and Lithuania explored the emotions of librarians toward teaching, finding librarians felt overall fairly positive, although they had less positive responses about feelings while teaching, the commitment required, and ambiguous expectations. ${ }^{4}$ For teaching librarians with public speaking anxiety, expectations to entertain students can exacerbate this problem, but the author identified potential support in concepts from the performing arts. ${ }^{5}$

In a follow-up article to Davis' research, Stephanie Schulte argues that, as the roles of academic librarians continue to include increasing amounts of instruction, with some librarians teaching semester-long credit courses, the issue of teaching anxiety will become increasingly important; more research is needed on this topic. ${ }^{6}$ This study seeks to move the conversation forward and provide updated and broader data on the issues around and contributors to teaching anxiety.

Another area of the literature explores anxiety in higher education. Pelton used the Teaching Anxiety Scale and the Teaching Confidence Scale to look at the impact of graduate 
training programs. ${ }^{7}$ Gardner and Leak found a high percentage (87\%) of their surveyed population (college psychologists) reported teaching anxiety. ${ }^{8} \mathrm{~A}$ study of the elements that most impact future success of new Geography faculty found that teaching was a significant source of anxiety, with lack of teacher training a primary factor. ${ }^{9} \mathrm{~A}$ survey of accounting professors reported 78 percent experienced teaching anxiety. The authors called for further research in higher education to see what variations might exist across disciplines. ${ }^{10}$ Houlihan et al. explored the effect of personality and teaching strategies across a range of disciplines using the Beck Anxiety Inventory. They determined that "higher neuroticism and lower extraversion were related to teaching anxiety."11

Teaching anxiety's potential connection to other types of anxiety also connects it to a growing body of literature invested in exploring mental illness within librarianship. This is reflected in recent publications, such as "Academic Librarians' Experiences and Perceptions on Mental Illness Stigma and the Workplace," in which the authors report on the results of a survey addressing the effects of mental health stigma on academic librarians. ${ }^{12} \mathrm{~A}$ forthcoming book, LIS Interrupted: intersections of mental illness and library work, seeks to bring to the forefront the experiences of library workers with mental illnesses. ${ }^{13}$

\section{Methods}

To gather information from librarians, the researchers created a survey in Qualtrics that used branched logic. The survey provided additional focused questions based on select responses. The authors drew upon Davis' 2007 survey; while the surveys are similar, there are important distinctions. Both surveys follow a similar structure. While Davis focused more on exploring issues of faculty rank and self and faculty perceptions, the researchers of this survey chose to focus more on how a librarian's role and their desire for that role relates to potential teaching anxiety. Davis also asked directly if respondents enjoy teaching and, if not, why not. This survey focuses on how they felt about teaching when they started and how prepared they felt when they started. Both surveys ask how much they teach and in which formats. Both surveys ask about physical and psychological symptoms (Davis refers to them as mental/emotional), and both ask about coping mechanisms.

Unlike Davis's study, this study also asks about formal diagnoses of other anxieties, as well as self-diagnosis of other anxieties. It asks about how teaching anxiety impacts someone's personal life and their work life, and if/how it has impacted library instructors' teaching in any positive ways. Both physical and psychological symptoms are inquired from a point of frequency and intensity. This survey also asked about what supports might be taken advantage of, if offered, as well as what barriers to support might exist. Davis's survey was 35 questions and received 382 completed and viable surveys. This survey was 47 questions in length and received 1,035 initial responses (see appendix). The researchers defined teaching for the purposes of the survey, and respondents who indicated they did not or had not previously taught and respondents under 18 years of age were immediately sent to a thank-you page at the end of the survey. Of those 1,035 respondents, 20 answered "no" to that question.

The researchers included a trigger warning within the risks section of the Informed Consent. After obtaining IRB approval, the survey was distributed to listservs covering a range of library roles, including instruction, administration, digital libraries, and scholarly communication, among others. Listservs initially included were ILI-L, College Lib, Lib Admin, 
ULS, RUSA, DLF-announce, LITA-L, Code-4-Lib, ALCTS-central, Scholcomm, Liblicense, and IFLA. The researchers sent out a prewritten email explaining the purpose of the research and invited responses from library staff with at least some component of teaching in their role. The survey remained open from May 15 to June 5, 2019, targeted during the summer months for maximum participation.

Analysis for much of the quantitative data was done through a series of bivariate statistical tests, each of which focused on whether one outcome variable is dependent upon one predictor variable. This aspect of the data analysis focuses on two dependent variables - the presence of teaching anxiety and the respondent's attitude toward teaching. The researchers primarily used chi-square tests, as those are best suited for examining categorical data. The researchers also include descriptive data looking at factors of teaching anxiety, symptoms, impacts, and supports.

The largest percentage of respondents were in the 31 to 40 age group $(36.16 \%, 354)$, with roughly equal percentages ages 41 to 50 and 50 and older ( $24 \%$ and $25.7 \%)$. The 18 to 30 age group comprised just under 14 percent of respondents $(13.89 \%, 136)$. The gender of the respondents was predominantly female with 81 percent (798), with 15 percent male respondents (151). Transgender, nonbinary, an identity not listed, or those who preferred not to answer comprised a little more than 3 percent of respondents each. Regarding the race and ethnicity with which respondents identified, White or Caucasian respondents comprised 84.6 percent $(n=821)$, with Hispanic or Latinx respondents comprising 3.69 percent $(n=37)$. No other race or ethnicity comprised more than 3 percent of respondents, although the number of respondents who preferred not to answer was 4.7 percent $(n=46)$.

Regarding type of institution respondents work for, the majority, 57.7 percent $(\mathrm{n}=561)$ work for a research university. Respondents also indicated they work for a liberal arts college $(21.5 \%, 209)$ or a community or technical college $(11.11 \%, 108)$. Respondents also had the option to indicate other types of institutions (9.67\%). The survey also asked respondents what type of teaching they do. Instruction in a discipline/department/college the respondent works with was selected by 46 percent $(n=745)$, instruction in topics they specialize in was chosen by 42 percent $(n=683)$ of respondents, and nonlibrary teaching was chosen by 11.69 percent $(n=189)$ of respondents.

\section{Findings}

Of the 925 people who answered the question "Do you experience teaching anxiety?" 600 $(64.94 \%)$ said yes. A total of 367 (39.68\%) of the 925 said they had been diagnosed with anxiety and $232(41.65 \%)$ of those who had not been formally diagnosed self-diagnosed with some form of anxiety. These data are difficult to compare, largely because survey participation was self-selected and is not representative of the field of librarianship as a whole. However, given the high response rate, the percentage of both teaching anxiety and diagnosis and/or self-diagnosis of other anxieties by library instructors appears high.

\section{Anxiety and Teaching}

Based upon the obtained $\chi^{2}\left(\chi_{(1)}^{2}=22.017, p<.001\right)$, there is a significant association between an official diagnosis of anxiety and experiencing teaching anxiety (see table 1). Among people who reported being diagnosed with anxiety, 74 percent experience anxiety when they teach. 


\begin{tabular}{|c|c|c|c|c|}
\hline \multicolumn{5}{|c|}{$\begin{array}{c}\text { TABLE } 1 \\
\text { Librarians' Experiences with Teaching Anxiety }\end{array}$} \\
\hline & Full Sample & $\begin{array}{l}\text { Teaching } \\
\text { Anxiety }\end{array}$ & No Anxiety & $\mathbf{P}$ \\
\hline Official diagnosis & & & & $<0.001$ \\
\hline Anxiety diagnosis & $n=365$ & $74.0 \%$ & $26.0 \%$ & \\
\hline No anxiety diagnosis & $\mathrm{n}=557$ & $58.9 \%$ & $41.1 \%$ & \\
\hline Position in library & & & & ns \\
\hline Instruction and/or Reference & $n=529$ & $63.7 \%$ & $36.3 \%$ & \\
\hline Other area & $\mathrm{n}=390$ & $66.4 \%$ & $33.6 \%$ & \\
\hline Past experience as an instructor & & & & ns \\
\hline Experience as library instructor/TA & $\mathrm{n}=743$ & $63.0 \%$ & $37.0 \%$ & \\
\hline No experience & $\mathrm{n}=142$ & $71.1 \%$ & $28.9 \%$ & \\
\hline Prior training as an instructor & & & & $<0.05$ \\
\hline Teaching coursework in MLS & $\mathrm{n}=358$ & $68.2 \%$ & $31.8 \%$ & \\
\hline No coursework & $\mathrm{n}=527$ & $61.7 \%$ & $38.3 \%$ & \\
\hline Teaching preparedness prior to hire & & & & $<0.001$ \\
\hline Very prepared & $\mathrm{n}=72$ & $37.5 \%$ & $62.5 \%$ & \\
\hline Prepared & $\mathrm{n}=209$ & $49.3 \%$ & $50.7 \%$ & \\
\hline Neutral & $\mathrm{n}=181$ & $63.5 \%$ & $36.5 \%$ & \\
\hline Unprepared & $\mathrm{n}=293$ & $72.4 \%$ & $27.6 \%$ & \\
\hline Very unprepared & $\mathrm{n}=160$ & $85.0 \%$ & $15.0 \%$ & \\
\hline Length in profession & & & & ns \\
\hline Less than 2 years & $\mathrm{n}=67$ & $61.2 \%$ & $38.8 \%$ & \\
\hline $2-4$ years & $n=133$ & $64.7 \%$ & $35.3 \%$ & \\
\hline $5-8$ years & $\mathrm{n}=186$ & $67.7 \%$ & $32.3 \%$ & \\
\hline $8-15$ years & $\mathrm{n}=249$ & $69.1 \%$ & $30.9 \%$ & \\
\hline 16-25 years & $\mathrm{n}=166$ & $62.7 \%$ & $37.3 \%$ & \\
\hline More than 25 years & $\mathrm{n}=114$ & $56.1 \%$ & $43.9 \%$ & \\
\hline Attitude toward future teaching & & & & $<0.001$ \\
\hline Teach more & $\mathrm{n}=266$ & $58.3 \%$ & $41.7 \%$ & \\
\hline Satisfied with current amount & $\mathrm{n}=341$ & $56.6 \%$ & $43.4 \%$ & \\
\hline Decrease current amount & $n=153$ & $77.8 \%$ & $22.2 \%$ & \\
\hline Opt out entirely & $\mathrm{n}=108$ & $87.0 \%$ & $13.0 \%$ & \\
\hline
\end{tabular}

\section{Position in Librarianship}

The researchers were interested in exploring a potential connection between teaching anxiety and the type of librarianship role with which the respondent identified; however, the data show there is not a significant association between teaching anxiety and library role. The majority of respondents identified with instruction and/or reference $(56 \%, 539)$, followed by administration/management $(8 \%, 77)$ (see table 1$)$. Almost 5 percent of respondents held roles in scholarly communication or copyright $(4.91 \%, 47)$ with approximately 4 percent of 
respondents holding roles in metadata and/or collection development and digital initiatives. Other areas of librarianship represented less than 3 percent for each.

\section{Teaching Anxiety and Past Training/Coursework}

While there was no significant association between teaching anxiety and previous teaching experience, based upon the obtained $\chi^{2}\left(\chi_{(1)}^{2}=3.907, p<0.05\right)$, there is a significant association between those who received training in information literacy/library instruction and experiencing teaching anxiety (see table 1). Those who had no coursework in their education experience were more likely to experience teaching anxiety.

\section{Preparedness and Past Training}

Based upon the obtained $\chi^{2}\left(\chi_{(1)}^{2}=81.680, p<.001\right)$, there was a significant association between teaching preparedness prior to being hired and teaching anxiety (see table 1). Among people who felt very prepared to teach, 37.5 percent reported experiencing anxiety. Among those who felt very unprepared to teach, 85 percent reported they experience teaching anxiety.

\section{Length in Profession}

The data show no significant association between length of time in the profession and teaching anxiety. For respondents with less than two years in the profession, 61.2 percent report they experience teaching anxiety. For each demographic up to 25 years in the profession, 60 to 70 percent of respondents report experiencing teaching anxiety (see table 1). The highest level of anxiety, at 69.1 percent, was reported by those with 8-15 years in profession. This shows anxiety is not necessarily going away with time or experience, and teaching anxiety is not just an issue for new librarians.

\section{Attitude toward Future Teaching}

Based upon the obtained $\chi^{2}\left(\chi_{(1)}^{2}=49.620, p<.001\right)$, there is a significant association between attitude toward future teaching and teaching anxiety. Among respondents who wanted to decrease the amount they teach, 77.8 percent experience teaching anxiety compared to 22.2 percent without teaching anxiety who want to decrease their amount of teaching (see table 1). For those wishing to opt out of teaching entirely, 87 percent experience teaching anxiety, while only 13 percent without teaching anxiety would choose to opt out of teaching.

\section{Role and Attitude toward Teaching}

Based upon the obtained $\chi^{2}\left(\chi_{(1)}^{2}=66.854, p<.001\right)$, there is a significant association between someone's role within the library and wanting to teach (see table 2). Respondents' attitudes toward teaching were significantly related to their position in the library, including whether the respondent was in a position primarily related to reference and instruction or if their primary role was in another area of librarianship. Upon entering the library profession, 33.1 percent of reference and instruction librarians wanted to teach versus 21.5 percent of respondents whose primary role was outside reference and instruction. Reference and instruction and other areas of librarianship were fairly equally open to teaching, but 18 percent of those in nonreference and instruction areas did not want to teach, versus 13.3 percent of those in reference and instruction who didn't want to teach. 


\begin{tabular}{|l|c|c|c|c|c|c|}
\hline \multicolumn{7}{|l|}{ TABLE 2 } \\
& $\begin{array}{c}\text { Full } \\
\text { Sample }\end{array}$ & $\begin{array}{c}\text { Wanted to } \\
\text { Teach }\end{array}$ & $\begin{array}{c}\text { Open to } \\
\text { Teaching }\end{array}$ & $\begin{array}{c}\text { No Plans } \\
\text { to Teach }\end{array}$ & $\begin{array}{c}\text { Didn't } \\
\text { Want to } \\
\text { Teach }\end{array}$ & \multicolumn{1}{|c|}{ P } \\
\hline Position in library & & & & & & $<0.001$ \\
\hline Instruction and/or Reference & $\mathrm{n}=526$ & $33.1 \%$ & $37.1 \%$ & $16.5 \%$ & $13.3 \%$ & \\
\hline Other area & $\mathrm{n}=405$ & $21.5 \%$ & $37.5 \%$ & $23.0 \%$ & $18.0 \%$ & \\
\hline Teaching preparedness prior to hire & & & & & & $<0.001$ \\
\hline Very prepared & $\mathrm{n}=71$ & $84.5 \%$ & $1.4 \%$ & $8.5 \%$ & $5.6 \%$ & \\
\hline Prepared & $\mathrm{n}=196$ & $61.7 \%$ & $21.4 \%$ & $12.2 \%$ & $4.6 \%$ & \\
\hline Neutral & $\mathrm{n}=188$ & $21.8 \%$ & $48.9 \%$ & $20.2 \%$ & $9.0 \%$ & \\
\hline Unprepared & $\mathrm{n}=312$ & $10.3 \%$ & $51.0 \%$ & $23.1 \%$ & $15.7 \%$ & \\
\hline Very unprepared & $\mathrm{n}=169$ & $4.1 \%$ & $32.5 \%$ & $24.3 \%$ & $39.1 \%$ & \\
\hline
\end{tabular}

\section{Preparedness and Attitude toward Teaching}

Preparedness matters for attitudes toward teaching. The data show that teaching preparedness when respondents entered the library profession is significantly associated with openness to teaching, based upon the obtained $\chi^{2}\left(\chi_{(1)}^{2}=393.842, p<.001\right.$ ) (see table 2). A minority of respondents felt very prepared, and 84.5 percent of those wanted to teach. Also, 2/3 of those who are very prepared do not experience teaching anxiety $(62.5 \%$, table 1$)$. Alternatively, 48.9 percent of the respondents who were open to teaching were neutral when asked whether they were prepared or unprepared (see table 2), and 2/3 of respondents who feel neutral about their preparedness experience teaching anxiety (see table 1). Of the respondents who did not want to teach when they entered the library profession, 54.8 percent felt unprepared or very unprepared, and 85 percent of those reporting to be unprepared when they entered the profession experienced teaching anxiety.

\section{Coping with Teaching Anxiety}

The most popular response to how respondents cope with teaching anxiety was "I spend a lot of time preparing for teaching" (33.80\%) (see table 3). Second in frequency, 21.32 percent reported talking to colleagues and friends about their struggles (communities of practice). Spending a lot of time preparing for teaching is significant because intermittent teaching makes this extensive preparation particularly problematic, as librarians may not get to re-

\begin{tabular}{|l|c|}
\hline \multicolumn{2}{|c|}{ Coping with Teaching Anxiety } \\
\hline Mechanisms for Coping with Teaching Anxiety & $\%$ of Respondents \\
\hline I spend a lot of time preparing for teaching & $33.8 \%$ \\
\hline I talk to colleagues and friends about my struggles (community of practice) & $21.32 \%$ \\
\hline I exercise & $11.57 \%$ \\
\hline I don't feel like I cope & $10.08 \%$ \\
\hline I take medication & $8.18 \%$ \\
\hline I receive counseling or therapy & $6.78 \%$ \\
\hline
\end{tabular}


use lessons since they teach for many different courses, especially in a one-shot scenario. In textual comments, librarians indicated anxiety around new classes and the first time in the semester they would teach a class. In addition to extensive preparation, library instructors may not build a routine or confidence in teaching due to its intermittent nature. The second most frequent response, talking to colleagues and friends about their struggles, could provide an opportunity. This response indicates that peer support can be a potential mitigating factor for teaching anxiety.

\section{Factors Contributing to Teaching Anxiety}

Table 4 shows the five most frequently selected responses regarding factors contributing to teaching anxiety. Factors 3 and 4, not having an opportunity to build rapport and lack of familiarity or discomfort with disciplinary content are unique to librarians. Quite often, librarians walk into a room with no built rapport and very little time to build it. Despite that, one of librarians' major outcomes is often to convince students to seek research help. Library instructors can also find themselves in a difficult position because their expertise is often not content knowledge in the subject areas that they are working with; instead, it is in the teaching and learning of information literacy across content areas. This can cause particularly acute imposter syndrome when faced with students and teachers who may assume that content knowledge is part of what they bring. Factors 1, 2, and 5 reflect the general context of teaching and working with students. The second factor, fears of being unprepared, have implications particularly for teaching librarians due to the range of courses many librarians work with and the competing demands of their roles.

\begin{tabular}{|l|l|c|}
\hline \multicolumn{2}{|c|}{ Factors Contributing to Teaching Anxiety } \\
\hline & Factors Contributing to Teaching Anxiety & $\%$ of Respondents \\
\hline 1 & Fear of looking foolish or unknowledgeable in front of others & $13.70 \%$ \\
\hline 2 & Fear of being unprepared & $12.73 \%$ \\
\hline 3 & No previous contact or rapport with students & $11.26 \%$ \\
\hline 4 & Lack of familiarity with disciplinary content/discomfort with content & $9.80 \%$ \\
\hline 5 & Fear of public speaking & $8.37 \%$ \\
\hline
\end{tabular}

\section{Physical and Psychological Symptoms}

Nearly two-thirds (65\%) of those who experience teaching anxiety experience physical symptoms (see table 5), mostly in the moderate range of intensity (52.16\%) (see table 6), while 73.43 percent experience psychological symptoms, with a similarly moderate intensity (53.72\%) (see table 5). Most respondents experienced three to four physical symptoms listed (40.1\%), which included the following: rapid or pounding heartbeat, shortness of breath, excessive sweating, dizziness, tremors or twitches ("nervous tics"), headaches, joint or muscle aches, fatigue or weakness, insomnia, upset stomach or gastrointestinal distress, and dermatological (such as blushing or hives) (see table 7). Textual responses included vocal changes, memory lapses, and shakiness. The most commonly selected physical symptoms were rapid or pounding heartbeat (19.16\%), upset stomach or gastrointestinal distress (15.19\%), and excessive sweating (13.4\%).

Those respondents experiencing psychological symptoms chose from the following list: feelings of apprehension or dread, negative self-talk, feeling restless or irritable, anticipating 
the worst, constantly watching for signs of danger, difficulty concentrating or "fogginess," or fears of unpreparedness/“tough questions." Forty-two percent of respondents felt three to four symptoms, followed by 33.8 percent who experience four to five symptoms. The most common selected psychological symptoms were feelings of apprehension or dread $(20.85 \%)$, fears of unpreparedness/“tough questions" (18.75\%), and anticipating the worst $(15.18 \%)$.

\begin{tabular}{|l|c|c|}
\hline \multicolumn{3}{|c|}{ TABLE 5 } \\
\multicolumn{3}{|c|}{$\begin{array}{c}\text { Presence of Physical and } \\
\text { Psychological Symptoms }\end{array}$} \\
\hline & $\begin{array}{c}\text { Experience } \\
\text { Physical } \\
\text { Symptoms }\end{array}$ & $\begin{array}{c}\text { Experience } \\
\text { Psychological } \\
\text { Symptoms }\end{array}$ \\
\hline Yes & $65.10 \%$ & $73.43 \%$ \\
\hline No & $34.90 \%$ & $26.57 \%$ \\
\hline
\end{tabular}

\begin{tabular}{|l|c|c|}
\hline \multicolumn{3}{|c|}{ TABLE 6} \\
\hline \multicolumn{1}{|c|}{ Intensity of Physical and Psychological Symptoms } \\
\hline & $\begin{array}{c}\text { Intensity } \\
\text { of Physical } \\
\text { Symptoms }\end{array}$ & $\begin{array}{c}\text { Intensity of } \\
\text { Psychological } \\
\text { Symptoms }\end{array}$ \\
\hline Very Intense & $2.43 \%$ & $4.80 \%$ \\
\hline Intense & $15.95 \%$ & $18.71 \%$ \\
\hline Moderate & $52.16 \%$ & $53.72 \%$ \\
\hline Minimal & $29.46 \%$ & $22.54 \%$ \\
\hline
\end{tabular}

TABLE 7

Number of Physical and Psychological Symptoms

\begin{tabular}{|l|c|c|}
\hline \# of Symptoms & Physical & Psychological \\
\hline Respondents w/1-2 symptoms & $35 \%$ & $24 \%$ \\
\hline Respondents w/3-4 symptoms & $40.1 \%$ & $42.2 \%$ \\
\hline Respondents w/5-6 symptoms & $24.8 \%$ & $33.8 \%$ \\
\hline
\end{tabular}

\section{Impact of Teaching Anxiety on Personal Life}

In response to the question of how their personal life been impacted, a few major themes arose. The most prevalent response focused on how experiences with teaching anxiety impacted sleep, sometimes described as loss of sleep (especially the night before), lack of sleep, insomnia, or other troubles sleeping. One respondent described it as: "Difficulty sleeping, loss of personal time since I prep so much for instruction, however I am new to it, so I feel it would get better the more I am allowed to do it, and I want more experience and opportunities to teach." Another described not being able to sleep because they were "making lists in my head over every possibility and back-up plan." Another stated, "[I] lack of desire to do anything else except fret about upcoming teaching assignment... even though I usually love it when I'm actually doing the teaching."

Other respondents noted its impact on their ability to socialize with friends and family, such as "I feel emotionally and physically exhausted when I get home, and need to rest and have an early night, which can impact ... my ability or desire to socialize after work." Another respondent stated, "Family leisure time regularly ruined." And another: "I constantly dread going to work and think about it much of the time at home so it impacts my family relationships."

Other emerging themes include feeling distracted, a difficulty in balancing work/life, mood effects, and panic attacks. One respondent noted the many ways teaching anxiety affected them, partly due to how infrequently they taught: "Because I teach infrequently and 
unpredictabl[y] throughout the year, I usually feel jitters and anxiety in the days before a planned class session. This can manifest in low mood, nervousness, poor night's sleep, feeling distracted from personal life."

\section{Positive Aspect of Anxiety}

When asked if/how their teaching anxiety contributed positively to their teaching, the most common response selected was that it helped them be a more reflective teacher $(32.64 \%)$, followed closely by those who selected that it increased their empathy with students $(29.11 \%$ ) (see table 8 ). In the comments section of the survey for this question, some respondents indicated their teaching anxiety caused them to be more prepared, providing statements similar to "I prepare

\begin{tabular}{|l|c|}
\hline \multicolumn{2}{|c|}{ TABLE 8} \\
Positive Aspects of Anxiety \\
\hline Positive Aspects & $\begin{array}{l}\text { Percentage of } \\
\text { Respondents }\end{array}$ \\
\hline More reflective teacher & $32.64 \%$ \\
\hline Increased empathy with students & $29.11 \%$ \\
\hline More effective teacher & $18.71 \%$ \\
\hline Mentorship of teaching colleagues & $12.16 \%$ \\
\hline Other & $7.38 \%$ \\
\hline
\end{tabular}
more than I would otherwise." A few also commented that they didn't understand the question, which may indicate that they don't see a positive aspect to their teaching anxiety experiences.

\section{Instruction Supports}

Respondents were most willing to participate in a course or workshop on teaching (25.62\%) and a course or workshop on coping with teaching anxiety or anxiety $(26.01 \%)$ (see table 9). Interestingly, support for teaching generally is nearly as emphasized as support for the condition of anxiety itself, which may speak to where the real issue lies. Structured groups of colleagues to talk to (18.65\%) and peer observations and feedback (17.57\%) each had just under 20 percent of respondents, indicating an interest in this type of support and suggesting a potential role for structured peer support.

When asked what barriers might prevent them from taking advantage of the supports discussed above, the most common answer was time and scheduling, followed by concerns about the effectiveness of the supports and the stigma of disclosing their experiences with teaching anxiety (see table 10). One recurring response noted in the "other" comments was the cost of supports.

\section{TABLE 9}

Potential Instruction Supports

\begin{tabular}{|l|c|}
\hline Supports & Percentage of Respondents \\
\hline Structured groups of colleagues to talk to & $18.65 \%$ \\
\hline Peer observations and feedback on my teaching & $17.57 \%$ \\
\hline Counseling and/or medical support & $10.14 \%$ \\
\hline A course or workshop(s) on teaching & $25.62 \%$ \\
\hline A course or workshop on coping with teaching anxiety or anxiety & $26.01 \%$ \\
\hline Other & $2.01 \%$ \\
\hline
\end{tabular}


TABLE 10

Factors Preventing Use of Supports

\begin{tabular}{|l|c|}
\hline Supports & Percentage of Respondents \\
\hline Stigma of disclosing that I suffer from teaching anxiety & $18.73 \%$ \\
\hline Fear of repercussions from colleagues & $12.59 \%$ \\
\hline Time and scheduling constraints & $37.46 \%$ \\
\hline Concerns about effectiveness of supports & $27.20 \%$ \\
\hline Other & $4.02 \%$ \\
\hline
\end{tabular}

\section{Discussion}

This research reveals librarians across the profession in a variety of roles are reporting a high level of teaching anxiety; it is not just relegated to librarians with nonteaching roles. One limitation of the study is that respondents were not randomly selected, but rather self-selected to submit the survey; however, the researchers attempted to mitigate this by distributing it broadly, evidenced by our strong response rate (over 1,000 usable responses).

One area of importance is the connection between how librarians feel about teaching in their role and whether they entered the profession wanting or planning to teach, which was significant with an increase in experiencing teaching anxiety. There is a strong relationship between those who want to opt out entirely of teaching and those who experience teaching anxiety (87\% who want to opt out experience it). This result poses an interesting question: What happens when one of the hats librarians are asked to wear may be more likely to cause them harm because they didn't want to wear it in the first place? Ideally, resources would allow libraries to hire more teaching librarians who wanted to teach, felt prepared to do so, and had support for that responsibility built into their workload. Most libraries lack the resources to do this, struggling with a balance between what many call functional specialists, such as data management or copyright, and more traditional liaison duties, such as instruction.

The intermittency of these types of situations is key. If a liaison model or other structure enables a teaching schedule that occurs very infrequently, the supports required to help that individual improve their teaching or successfully cope with resulting anxiety are likely going to feel unequal to the cost/benefit. Why spend hours in training and support situations for something that only happens occasionally? However, the reality may be that the occasional teaching opportunity is having a major impact on that person's home/life balance, perception of their work, and attitude toward the organizational structures imposed on them that require them to teach.

Findings also indicate a tension between sustaining a work-life balance for those struggling with teaching anxiety. If the model of required teaching responsibilities from many different librarianship roles can continue without causing undue stress on library instructors, the library profession, and especially those in administrative positions, needs to acknowledge what it takes to adequately support teaching. These findings suggest that the number of sessions, or hours, a librarian teaches per day or week is key and can often exhaust or take over other responsibilities, which is necessary when considering what else that person is being asked to do. Libraries could consider limiting the number of sessions a librarian can commit to in a day or week, something most nonlibrarian teaching faculty naturally have built in for them as part of their teaching loads. One way to help accomplish this is through curriculum mapping, or identifying the most strategic and impactful times for librarians to meet with classes throughout a program of study. 
In general, acknowledging the ambiguity of how to "count" library teaching in comparison to the way it is so neatly counted for others in academia is critical. Library teaching is uniquely distinct, as illustrated by many of the comments from participants. One participant expresses it this way:

Library teaching, specifically for "one shots" is very different from teaching a full course. It can feel like you are a substitute teacher, be more difficult to gain students attention or interest, you are reliant on faculty to give you information to prepare which they are often slow or incomplete with, or they can correct you in class. On top of it all, you rarely get to see the outcome of your efforts and it is hard to know if your hard work and anxiety was worth it or made a difference.

Not only can library instruction not be measured for workload purposes in the same way, its emotional toll and impact on the instructor are also unique. As this quote illustrates, the brief view and interactive moment that library instructors get with students, rife with anxiety-inducing factors in itself (disinterested students, demanding instructors, insufficient collaboration, and so on) is often exacerbated by the inability to see a result, to see what the endless preparation might have wrought for student learning. Even the best one-shot assessments cannot always reinforce that their effort made a difference.

Additional teaching supports may help alleviate some of these concerns. Supports and training for effective library instruction, such as how to manage a classroom, design a curriculum, and collaborate with an instructor are essential. This is especially important considering that results indicated time in the field is not significantly correlated to teaching anxiety. Participants who had been in the field less than two years up to those who had been in the field for up to 25 years all experienced teaching anxiety within a range of 61.1 to 69.1 percent. Considering how much the traditional role of a reference librarian has shifted toward library instruction, the sustained high level of teaching anxiety for those with major or minor instructional roles is understandable. Comments throughout the survey indicate that some librarians view teaching as being the center of attention, which fuels anxiety. Concerns about how to present content also contribute to anxiety. One respondent indicated a "fear of not being engaging/creative enough or boring the audience," while others noted these observations: "The planning is extremely difficult. It is very hard for me to figure out what to teach and how to structure it so it will be meaningful," and "Lack of classroom management skills, fear of inability to engage students" as contributors to teaching anxiety. Libraries could play a larger role with assistance in lesson plan development, particularly principles of active learning that enable librarians to facilitate learning activities rather than standing in front of a class and presenting content with the associated stress and stage fright.

Content area knowledge emerged as a contributor to teaching anxiety; 9.8 percent of respondents selected this as a factor. One librarian indicated anxiety "definitely flares when I don't feel confident about the subject matter." Expectations about what librarians should know about the subject areas they support in the context of liaison work can be murky at best. It is not uncommon for liaison areas to be exchanged among librarians and for librarians to have varying levels of understanding and immersion in that subject area, ranging from very little to undergraduate- or graduate-level degrees in the subject. Librarians need clearer, consistent expectations about what their role is in relation to the populations they serve and 
to understand expectations for growth and how they will be supported to fulfill those. It is library administration's job to help define this locally for their institutions and to share these with librarians doing the work, and more widely with university faculty, administration, and students.

Additionally, emotional supports are key. Anxiety, especially teaching anxiety, is a significant issue according to our data. Nearly three-fourths (74\%) of the 64.94 percent experiencing teaching anxiety were also either self-diagnosed or formally diagnosed with anxiety, which skews high in comparison to global and national data. Globally, 3.76 percent of the worldwide population suffered from anxiety in $2017 .{ }^{14}$ National data depicts that 6.64 percent of the U.S. population suffered from an anxiety disorder as of $2017 .{ }^{15}$ Libraries need to recognize this issue and its intersection with our profession, work toward a more open environment, and invite discussions among librarians with teaching roles. More open conversations that acknowledge the high levels of teaching anxiety among librarians, both within and outside of traditional reference and instruction roles, is an important step toward developing meaningful supports. Respondents indicate a need for a community of peers with whom to share, decompress, and grow. This can be difficult to facilitate as an institution. Survey respondents demonstrate a willingness to engage in some type of supports, but they also demonstrate a lack of trust in the system to provide it to them. It takes time and careful planning to successfully implement programs that provide ongoing support and growth. While grassroots communities that grow outside of formal organizational structures can also be effective, they should not be the only solution for those seeking support. Carefully organized mentoring or peer observations focused on positive support and growth rather than evaluation should also be considered.

\section{Conclusion}

It continues to be necessary for librarians to enter the field prepared with skills for a wide breadth of responsibilities, but the profession must commit to supporting those roles and authentically address how those tasks affect the people who perform them, including the subsequent emotional, physical, and mental consequences.

The next phase of our research aims to delve more deeply into the unique experiences of individual librarians dealing with teaching anxiety, as well as the unique structures of their roles and organizations. The researchers will also look more closely at how those structures enable or limit potential supports for teaching anxiety, further detailing what effective supports might look like.

All of these solutions require time, consideration, and resources. This is not a convenient truth for libraries who often depend on distributed instructional labor, but it is a necessary one. Better supporting librarians experiencing teaching anxiety and creating structures that limit the factors that correlate with it, the more likely libraries are to provide a learning environment where students and library instructors thrive. 


\section{APPENDIX}

Q1. Did you previously or do you currently teach as part of your library role?

Conditional:

$\quad$ Yes - go to Q2

No - Ends survey.

\section{BLOCK: Demographic}

Q2 What is your age in years?

- 17 and under

18-30

口 31-40

$\square \quad 41-50$

51+

Q3 With which gender do you identify? (Select all that apply.)

$\square$ Woman

口 Man

$\square \quad$ Trans or Transgender

$\square$ Nonbinary

$\square$ An identity not listed, please self-identify:

$\square \quad$ Prefer not to answer

Q4 With which race/ethnicity do you identify? (Select all that apply.)

$\square$ African American or Black

- American Indian or Alaska Native

- Asian American or Asian

$\square$ Hispanic or Latinx

$\square$ Middle Eastern or North African

$\square$ Multiracial

口 Pacific Islander

$\square \quad$ White or Caucasian

$\square$ An identity not listed, please self-identify:

$\square \quad$ Prefer not to answer

Q5 How long have you been in the library profession as staff and/or faculty?

$\square \quad$ Less than 2 years

2-4 years

5-8 years

$\square \quad 9-15$ years

$\square \quad 16-25$ years

25+ years

Q6 What type of institution do you work for?

$\square$ Community College/Technical College

- Liberal Arts College

- Research University

- Other:

Q7 What is your current status?

口 Staff 
$\square$ Faculty

$\square$ Continuing Appointment

$\square$ Professional Status

$\square$ Other:

\section{BLOCK: Library Role 1}

Q11 What area of librarianship do you currently most identify with as your major role?

$\square$ Acquisitions and/or Collection Development

$\square$ Administration/Management

$\square$ Assessment

$\square$ Circulation

$\square \quad$ Digital Initiatives

$\square \quad$ Instruction and/or Reference

$\square \quad$ Metadata or Cataloging

$\square$ Research Data Management

$\square$ Scholarly Communications and/or Copyright

$\square$ Special Collections and/or Archives

$\square$ Systems/IT

$\square$ Other:

Q12 What higher education/professional degree(s) have you achieved? (Select all that apply.)

$\square \quad$ None

$\square$ Associate

$\square$ Bachelor

$\square$ MLIS/MLS/MIS

$\square$ Master, not MLIS

$\square \quad \mathrm{PhD} / \mathrm{DPhil}$

$\square \quad$ EdD

$\square$ Other(s):

Q13 What sort of past training or experience have you had in teaching? (Select all that apply.)

$\square$ Coursework in my MLS

$\square$ Coursework in a nonlibrary-related degree

$\square$ Experience as a library instructor

$\square$ Experience as a teaching assistant or instructor for nonlibrary courses

$\square$ Other:

Q14 When you entered the library profession, how did you feel about teaching? (Select all that apply.)

$\square \quad$ I really wanted to be a teacher

$\square \quad$ I was open to teaching but had never done it

$\square \quad$ I had no plans to teach

I didn't want to teach

Q15 When you entered the library profession, how prepared did you feel to teach?

$\square$ Very unprepared

$\square$ Unprepared

$\square$ Neutral 
$\square \quad$ Prepared

$\square \quad$ Very prepared

\section{BLOCK Library Role 2}

Q16 What type of teaching do you do? (Select all that apply.)

$\square$ Instruction in a discipline/department/college I work with (that is, business, history, government information, writing, communication, or social sciences)

$\square$ Instruction in topics I specialize in (that is, citation management, data visualization, data management, and others)

$\square$ Nonlibrary teaching (that is, teaching for a department or course on campus outside of the library)

Q17 Which formats do you use to teach? (Select all that apply.)

$\square$ Face-to-face

$\square$ Online (asynchronous)

$\square$ Broadcast or synchronous online mediums

$\square$ Hybrid

$\square$ Other:

Q18 In the following questions, we are referring to your current role:

Likert Answers: Not at all, Occasionally, Neutral, Regularly, Always

$\square \quad$ I feel confident in my abilities as an instructor

$\square \quad$ I enjoy teaching

$\square \quad$ I feel uncomfortable when I teach

$\square \quad$ I prepare extensively for my teaching

Q19 What percentage of your current role is teaching?

․ $1 \%-5 \%$

․ $6 \%-10 \%$

ㅁ $11 \%-25 \%$

$\square \quad 26 \%-40 \%$

ㅁ $41 \%-60 \%$

ㅁ $61 \%-80 \%$

․ More than $80 \%$

Q20 How much do you teach on average? Sessions refers to course-integrated library sessions, such as one-shots. (Select all that apply.)

$\square$ For-credit course(s) every semester or annually

$\square$ For-credit course occasionally

$\square \quad 1-5$ sessions per semester

ㄴ 6-15 sessions per semester

$\square \quad 16-30$ sessions per semester

$\square \quad 31-45$ sessions per semester

$\square \quad$ More than 45 sessions a semester

Q21 Would you opt out or decrease your teaching role if you could?

$\square \quad$ Yes, I would opt out entirely of teaching.

$\square \quad$ Yes, I would decrease my teaching role.

$\square \quad$ No, I am satisfied with the amount of teaching I do.

$\square$ No, I would teach more if I could.

$\square$ Other (Please explain): 


\section{BLOCK: Diagnosed}

Q23 Have you ever been diagnosed for anxiety of any kind?

Conditional:

No, go to Q40 then Q46

Yes, go to Q46

\section{BLOCK: Self-identity}

Q40 Do you self-identify with anxiety though you have not been formally diagnosed?

口 Yes

$\square$ No

Q46 Do you experience teaching anxiety?

Conditional:

Yes, go to Q34

$\square \quad$ No, end survey.

\section{BLOCK: Does it impact your personal life?}

Q34 Does your teaching anxiety impact your ability to function in your personal life?

Conditional:

Yes, a lot-go to Q42

․ Yes, a little-go to Q42

№-go to Q26

\section{BLOCK: Yes, it impacts my personal life}

Q42 Please describe briefly how your personal life has been impacted.

Open Text

Q22 How often do you feel anxious in your day-to-day life?

$\square \quad$ All the time

$\square$ Sometimes

$\square$ Rarely

$\square$ Never

\section{BLOCK: Yes, I experience teaching anxiety}

Q26 When do you feel teaching-related anxiety? (Select all that apply.)

$\square$ When I am teaching in front of a group

$\square \quad$ Prior to teaching a group, while I am preparing

- After teaching a group, while I am reflecting on how it went

․ When I am teaching material/content I'm not as comfortable with

$\square$ When I am teaching students

$\square$ When I am teaching staff or faculty

$\square$ I don't

$\square$ Other:

Q33 How does your teaching anxiety impact your ability to function at work? (Select all that apply.)

It makes teaching tasks difficult

It makes nonteaching tasks difficult

It doesn't impact my functioning at work 
Q32 What factors contribute to your teaching anxiety? (Select all that apply.)

$\square$ Presence of an instructor with content discipline

․ No previous contact or rapport with students

$\square$ Dependence on technology and tools

- Scope of expected learning goals to be covered

$\square$ Discomfort with the physical space

口 Time constraints

口 Lack of familiarity with disciplinary content/discomfort with content

$\square$ Fears of being unprepared

$\square \quad$ Fear of public speaking

- Fear of looking foolish or unknowledgeable in front of others

口 Fear of forgetting

$\square$ Fear of teaching particular populations (that is, fear of teaching faculty)

口 Other:

Q35 How do you cope with teaching anxiety? (Select all that apply.)

$\square \quad$ I take medication

I I exercise

$\square \quad$ I receive counseling or therapy

․ I spend a lot of time preparing for teaching

I talk to colleagues and friends about my struggles (community of practice)

I don't feel like I cope

$\square$ Other:

Q36 If you experience teaching anxiety, has it impacted your teaching in positive ways?

(Select all that apply.)

$\square$ Mentorship of teaching colleagues

- Increased empathy with students

- More effective teacher

- More reflective teacher

$\checkmark$ Other: Please explain

\section{BLOCK: Physical Symptoms}

Q43 Do you have physical symptoms of anxiety?

Conditional:

Yes-go to Q27

No-skip to Q44

\section{BLOCK: Yes, Physical Symptoms}

Q27 What physical symptoms do you experience in a teaching setting? (Select all that apply.)

$\square$ Rapid or pounding heartbeat

$\square$ Shortness of breath

$\square \quad$ Excessive sweating

$\square$ Dizziness

口 Tremors or twitches ("nervous tics")

$\square$ Headache 
$\square \quad$ Joint or muscle aches

$\square \quad$ Fatigue or weakness

$\square$ Insomnia

$\square$ Upset stomach or gastrointestinal distress

$\square$ Dermatological (that is, blushing or hives)

$\square$ I don't experience physical symptoms

$\square$ Other:

Q28 As a whole, how intense are your physical symptoms?

$\square$ Very intense

$\square$ Intense

$\square$ Moderate

$\square$ Minimal

Q29 How often do you experience your physical symptoms?

$\square \quad$ Very often

$\square$ Often

$\square$ Sometimes

$\square$ Rarely

\section{BLOCK: Psychological symptoms}

Q44 Do you have psychological symptoms of anxiety?

Conditional

$\square \quad$ Yes-go to Q41

$\square$ No-skip to Q37

Q41 What psychological symptoms do you experience in a teaching setting? (Select all that apply.)

$\square$ Feelings of apprehension or dread

$\square \quad$ Negative self-talk

$\square \quad$ Feeling restless or irritable

$\square$ Anticipating the worst

$\square$ Constantly watching for signs of danger

$\square$ Difficulty concentrating or "fogginess"

$\square$ Fears of unpreparedness/“tough questions"

$\square \quad$ I don't experience psychological symptoms

$\square \quad$ Other: Please specify

Q30 As a whole, how intense are your psychological symptoms? (Select all that apply.)

$\square$ Very intense

$\square \quad$ Intense

$\square$ Moderate

$\square$ Minimal

$\square \quad$ I don't experience psychological symptoms

Q31 How often do you experience your psychological symptoms in a teaching setting?

$\square$ Very often

$\square$ Often

$\square$ Sometimes

$\square$ Rarely 


\section{BLOCK: Support \& Looking Forward}

Q37 If support was offered, which supports would you take advantage of? (Select all that apply.)

口 Structured groups of colleagues to talk to

$\square$ Peer observations and feedback on my teaching

$\square$ Counseling and/or medical support

$\square \quad$ A course or workshop(s) on teaching

$\square$ A course or workshop on coping with teaching anxiety or anxiety

$\square$ Other:

Q38 Which factors would prevent you from taking advantage of these supports? (Select all that apply.)

口 Stigma of disclosing that I suffer from teaching anxiety

$\square$ Fear of repercussions from colleagues

$\square$ Time and scheduling constraints

$\square$ Concerns about effectiveness of supports

$\square$ Other:

Q39 Any additional comments you would like to share?

Open Text

Q47 Are you interested in participating in a follow-up phone survey to help determine supports for teaching librarians with anxiety?

\section{Notes}

1. Parker Palmer, The Courage to Teach: Exploring the Inner Landscape of a Teacher's Life, 1st edition (San Francisco, CA: Jossey-Bass, 1998).

2. Kaetrena D. Davis, “The Academic Librarian as Instructor: A Study of Teacher Anxiety," College $\mathcal{E}$ Undergraduate Libraries 14, no. 2 (June 2007): 77-101, https://doi.org/10.1300/J106v14n02_06.

3. Heidi Julien and Shelagh K. Genuis, "Librarians' Experiences of the Teaching Role: A National Survey of Librarians," Library \& Information Science Research 33, no. 2 (April 1, 2011): 103-11, https://doi.org/10.1016/j. lisr.2010.09.005.

4. Vincas Grigas, Roma Fedosejevaite, and Anna Mierzecka, “Librarians as Educators: Affective Dimensions Experienced in Teaching," in Information Literacy: Key to an Inclusive Society, eds. Serap Kurbanoğlu et al., Communications in Computer and Information Science (New York, NY: Springer International Publishing, 2016), 619-33.

5. Sarah Polkinghorne, "Unpacking and Overcoming 'Edutainment' in Library Instruction," In the Library with the Lead Pipe, September 9, 2015, www.inthelibrarywiththeleadpipe.org/2015/edutainment/.

6. Stephanie J. Schulte, "More Research Needed on Librarian Teaching Anxiety," Evidence Based Library $\mathcal{E}$ Information Practice 4, no. 4 (December 2009): 74-77.

7. Julie A. Pelton, "Assessing Graduate Teacher Training Programs: Can a Teaching Seminar Reduce Anxiety and Increase Confidence?" Teaching Sociology 42, no. 1 (January 1, 2014): 40-49.

8. Louis E. Gardner and Gary K. Leak, "Characteristics and Correlates of Teaching Anxiety among College Psychology Teachers," Teaching of Psychology 21, no. 1 (February 1994): 28-32, https://doi.org/10.1207/ s15328023top2101_5.

9. Michael N. Solem and Kenneth E. Foote, “Concerns, Attitudes, and Abilities of Early-Career Geography Faculty," Annals of the Association of American Geographers 94, no. 4 (December 2004): 889-912, https://onlinelibrary. wiley.com/doi/abs/10.1111/j.1467-8306.2004.00440.x.

10. Michael Houlihan et al., "Personality Effects on Teaching Anxiety and Teaching Strategies in University Professors," Canadian Journal of Higher Education 39, no. 1 (March 1, 2009): 61-72.

11. Houlihan et al., "Personality Effects on Teaching Anxiety and Teaching Strategies in University Professors."

12. Erin Burns and Kristin E.C. Green. Academic Librarians' Experiences and Perceptions on Mental Ill- 
ness Stigma and the Workplace. College \& Research Libraries 80 no. 5 (July 2019): 638-657, https://doi.org/10.5860/ crl.80.5.638.

13. Office of the Gender and Women's Studies Librarian, UW-Madison Libraries, “CFP: LIS Interrupted: Intersections of Mental Illness and Library Work," https://www.library.wisc.edu/gwslibrarian/2018/12/10/cfplis-interrupted-intersections-of-mental-illness-and-library-work [accessed October 24, 2019].

14. Hannah Ritchie and Max Roser, "Mental Health," Our World in Data, January 20, 2018, https://ourworldindata.org/mental-health.

15. "Anxiety in the U.S.," Statista, accessed October 2, 2019, https://www.statista.com/study/61559/anxiety-inthe-us/. 